Research Article

\title{
CONTRIBUTION OF ZAKAT AND COMMUNITY ECONOMIC WELFARE
}

\author{
Muhammad Kamil Husain* \\ Universitas Serang Raya
}

\author{
Article history: \\ Submission 25 June 2021 \\ Revised 29 June 2021 \\ Accepted 30 June 2021 \\ *Corresponding author: \\ E-mail: \\ kamilhusain74@yahoo.com
}

\begin{abstract}
This research aimed to discuss zakat in the context of contribution and community economic welfare in the perspective of zakat institutionalization and regulation, sources of foreign exchange, and distribution of capital and human development. The method used was the qualitative approach through academic literature to obtain the concepts that were relevant to the study of zakat and the community economic welfare. The data analysis process was based on the theory and concept of zakat and then followed by the data interpretation process later on. The research results showed that the dimensions of zakat institutionalization and regulation, sources of foreign exchange, and distribution of capital and human development had a very strong pattern and relationship with the dimension of community economic welfare, and this was because these three dimensions were the important determinants of the contribution of zakat for the community economic welfare. On the other hand, the instrument of community economic welfare through the zakat mechanism needs to be continuously encouraged with the awareness of the entire community to pay zakat, increase the effectiveness of zakat management, and strengthen the zakat regulations.
\end{abstract}

Keywords: Zakat, Economic welfare, Community

\section{Introduction}

Poverty and community economic welfare are like two sides of the same coin. Indonesia is a country with a 270 million population, yet the poor reached 27.55 million people or 10.19 percent in September 2020, with an average poor household having 4.83 members. Thus, the average poverty line per poor household was Rp.2,216,714/poor household/month (BPS, 2021). This condition shows that Indonesia is still faced with poverty problems and the community economic welfare that has not yet been achieved.
One of the efforts in overcoming the poverty problem from a religious perspective is the contribution of zakat through fertilization and capital formation. In this case, zakat has an important role to improve the quality of human resources which is expected to have an impact on health and access to education. This is supported by the role of Muslims who are the majority religion in Indonesia through the contribution of zakat as a solution to improve the community economic welfare.

In addition, there is synergy and collaboration between the government, ulama, and zakat

\section{How to cite:}

Husain, M. K. (2021). Contribution of zakat and community economic welfare. Indonesian Journal of Social Science Research, 2(1), 39 - 43. doi:10.11594/ijssr.02.01.06 
collector institutions (amil), and community support, especially Muslims, to continuously raise public awareness to pay zakat, therefore the purpose of zakat to improve the community economic welfare can be realized. However, there are still problems that cause the contribution of zakat to the community economic welfare is not yet optimal, such as the zakat economic utilization is not yet ideal, and the impact of zakat on the community economic welfare is still low.

Particularly in Indonesia and generally in the world of Islam, zakat is already believed to be the main point of Islamic teachings that must be fulfilled. Zakat is seen as one of the five pillars of Islam; the five pillars of Islam are the shahada, salah, zakat, fasting, and hajj. Zakat is obligatory, and as such has been seen as a sin for anyone who leaves it, and otherwise will get a reward for those who carry it out (Hafidhuddin, 2008). Different theoretical contexts were put forward by those who further elaborated on the meaning of zakat in terms of language as follows: 1) Growing, meaning it shows that objects subject to zakat are objects that grow and reproduce (either by themselves or through effort, especially with a mixture of both); and if the object has been given zakat, then it will grow and multiply, as well as grow the human and religious mentality of the owner (muzakki) and the recipient (mustahik); 2) Good, meaning that the property subject to zakat is a good quality object, and if it has been given zakat, its quality will increase further and will improve the quality of its muzakki and mustahik; 3) Blessings, meaning that the objects subject to zakat are objects that contain blessings (in a potential sense). It has potential for the economy and brings blessings to everyone involved in it if the zakat has been paid; 4) Sacred, meaning that the object that is subject to zakat is sacred. Pure from illegitimate business, as well as smooth from pest and disease disturbances, and if zakat has been paid, he can purify the muzakki's mentality from bad morals, indecent behavior, and sin, as well as for his mustahik; 5) Excess, meaning that the object of zakat is an object that exceeds the basic needs of muzakki, and is expected to meet the basic needs of mustahik.
The theoretical context of zakat and community welfare was put forward by (Ismail, 2005) who explained the urgency of zakat in community welfare, among others as follows: Zakat Institutionalization, regulations, sources of foreign exchange, the absence of guarantees in transactions, Means of implementing pure Islamic economic products, Capital distribution, Establishment of financial institutions, and Industrial Development. Zakat, in terms of an ethnic approach and rational economic thinking, is an economic policy that can elevate the status of the poor, therefore the expected social impact can be achieved maximally (Dzikrulloh \& Permata, 2019). The context of zakat has six principles. First, the principle of religious belief; namely that people who pay zakat is a manifestation of their religious beliefs. Second, the principle of equity and justice; the social goal of zakat is to distribute the wealth given by Allah more evenly and fairly to humans. Third, the principle of productivity; emphasizes that zakat must be paid because a certain property has produced certain products after a certain period has passed. Fourth, the principle of reason; It is very rational that zakat on the property that produces it must be issued. Fifth, the principle of freedom; Zakat is only paid by free people. Sixth, the principles of ethics and fairness; namely zakat are not collected arbitrarily (Mannan, 1993, in Bahri, 2013).

(Murtala et al., 2011) said that one of the efforts to increase community contribution is the growing trust of zakat payers because their absence will damage the effectiveness of zakat institutions. Unlike other forms of voluntary donations, zakat is a religious obligation guided by divine rules. Zakat is a mechanism and social work, the practice of helping people to overcome poverty and make a social change at the community, organizational, and international levels (Ali \& Hatta, 2014), and comprehensively Bremer (2013) said that Zakat was not only a means to provide welfare social benefits for those at the bottom of society, but also a practical mechanism for setting some boundaries around inequality. Since the obligation of zakat is based on assets, at least in principle, the payment of zakat transfers part of the assets of 
those who have accumulated wealth to the poorest people.

Research on zakat in the context of economic welfare conducted by Khasandy \& Badrudin (2019) showed that zakat in Indonesia did not affect economic growth and community welfare. In addition, the welfare of the Indonesian people as a developing country has a negative value to the HDI and GINI indexes, and has a positive value to the percentage of poor people. Meanwhile, different research results were presented by al-Salih (2020), which showed that Zakat had a positive impact on social welfare and economic sustainability in Saudi Arabia. Furthermore, Ibrahim et al. (2020) in their research through the results of the distribution simulation model, proved the ability of zakat in narrowing income inequality, reducing income loss, and thereby improving the welfare of people in Malaysia.

Next, the zakat research in the perspective of zakat institutional approach and community economy was put forward by Yusoff (2008) who said that zakat institutions should have had a long-term program to teach poor and needy people to know how to catch fish rather than just annually gave them fish to eat. Researchers believe that zakat funds will be more effective if they are used as long-term investments and improve the capabilities and skills of human resources or the community. This is based on the assumption that zakat funds used in the short term are only temporary and do not have a significant impact on the economic welfare of the community.

This research aimed to discuss zakat in the context of the contribution and community economic welfare in the perspective of zakat institutionalization, regulations, sources of foreign exchange, the absence of guarantees in transactions, means of implementing pure Islamic economic products, distribution of capital, formation of financial institutions, and industrial development.

\section{Method}

The method used was a qualitative approach. The technique used by researcher was a survey of academic literature to obtain the concepts relevant to the study of zakat and the community economic welfare. The technique of collecting the data was through searching various sources and literature, both from government documents as well as printed and electronic mass media reports, journals, and books related to zakat literature and the community economic welfare. The secondary data were processed and described in the form of a narrative according to the data needs. Furthermore, the data analysis process was carried out based on the theory and concept of zakat, and then followed by the data interpretation process.

\section{Result and Discussion Zakat Institutionalization and Regulation}

The official institution that oversees the distribution of zakat is the Amil Zakat National Agency (BAZNAS) which is located at the central and regional levels. Based on Law no.23 of 2011 concerning Zakat Management regulates planning, collection, distribution, and utilization activities, and thus the Amil Zakat National Agency (BAZNAS) is formed for the central, provincial, and district/city. BAZNAS is a nonstructural government institution that is independent and responsible to the President through the Minister. BAZNAS is also an institution authorized to carry out the task of managing zakat nationally. In addition to the establishment of BAZNAS, which is an independent institution, the community can form the Amil Zakat Institution (LAZ) through the initiative of the private sector which must obtain permission from an authorized official such as the Minister or an official appointed by the relevant Minister and must report its activities periodically to the authorized official. In addition to receiving zakat, BAZNAS or LAZ can also receive infak, alms, and other religious social funds.

The Amil Zakat Institution in Indonesia is a zakat management institution formed by the community so that it has no affiliation with the Amil Zakat Agency (Sudirman, 2007) as a form of community participation, as stated in Law Number 23 of 2011 concerning Zakat Management, and acts as a functional operator managing zakat assets, even though its position is under BAZNAS in the new Zakat Management Law (Ramadhita, 2012). The zakat institution is an agency that manages the sources of zakat funds received from muzakki, both individuals and business entities following applicable Islamic 
rules, both zakat al-Fitr and zakat al-mal as well as zakat in other forms such as infak and sadaqah (Holil, 2019). Thus, the accountability and transparency of the Amil Zakat Agency and LAZ is an important factor in optimizing the institutionalization of zakat and regulations.

\section{Sources of Foreign Exchange}

As an instrument of state income, zakat has enormous potential although, in the aspect of state finances, zakat in Indonesia has not been managed by the government and even tends to be neglected (Subekan, 2012). Zakat has similarities with taxes as a source of foreign exchange, however, there are some differences between the two as stated by (Rahman, 2002), namely: 1) Zakat is a religious obligation and a form of worship, while taxes are generally an economic policy that is applied to earn income for the community. government; 2) Zakat is obligatory on all Muslims in a country, while taxes are generally imposed on the entire community without considering caste, religion, or skin color; 3) Zakat is a religious obligation for Muslims that must be paid under any circumstances without being avoided. On the other hand, taxes can be withheld by the government in power; 4) The source and amount of zakat are determined based on the holy books of the Qur'an and Sunnah and cannot be changed by anyone or the government. On the other hand, the source and amount of tax may be changed from time to time based on the needs of a country's government; 5) Items of expenditure and those who are entitled to receive zakat assets are also stated in the Qur'an and Sunnah and no one or any government has the right or power to change these provisions, while tax expenditures can be changed or modified according to the needs of the government.

The synergy of zakat and tax payments is expected to encourage an increase in zakat and tax revenues proportionally. In this case, comprehensive zakat and tax data can be an opportunity for all stakeholders and in the long term will realize efficiency and effectiveness in zakat and tax collection which so far seem to be two "worlds" that are far apart (Fajarudin, 2019). Thus, in the perspective of economic welfare, zakat can play an important role in supporting sustainable economic development through state revenue receipts, and conceptually, zakat is an instrument of government programs in poverty alleviation.

\section{Distribution of Capital and Human Develop- ment}

Viewed from the Islamic economic system, zakat is one of the financial instruments to achieve the goals of socio-economic justice and the distribution of wealth and income, by acclamation it is seen as an inseparable part of Islamic moral philosophy and is based on a definite commitment to human brotherhood (et al., 2018). Zakat is interpreted in Islamic law to help people who are lacking in their economic life, therefore they do not need guarantees in transactions. The absence of this guarantee means opening up opportunities for the poor to try to change their lives to be prosperous so that in the future they will become muzakki and no longer mustahik (Ridho, 2014). Through zakat, the mechanism for collecting capital for financing can be carried out. Zakat is one of the characteristics of the Islamic economic system because zakat is one of the implementations of the principle of justice in the Islamic economic system.

Human development has a broader meaning than economic growth, more than just increasing income and the process of producing goods and capital accumulation (Karuni, 2020), and Human development is defined as a process of increasing the capability of humans or populations to be able to participate in all areas of development, as well as can lead a healthy and productive life in society (Alkire, 2010). The concept of zakat explains that the wealth of the rich is used to enrich and build the poor, which later the poor will become affluent people who can pay zakat (Hassan, 2010), thus it can be said that there is a very strong relationship between zakat and human development capital.

\section{Conclusions}

Zakat is an implementation of the principles of welfare and justice in Islam with a multiplier effect for individuals, society, and the state. The context of zakat and the community economic welfare includes three dimensions: zakat institutionalization and regulations, sources of 
foreign exchange, and distribution of capital and human development. These three dimensions have a very strong pattern and relationship with the dimension of the community economic welfare, for these three dimensions are important determinants for the zakat contribution to the community economic welfare. The instrument of community economic welfare through the zakat mechanism needs to be encouraged with the awareness of the whole community to pay zakat, increase the effectiveness of zakat management, and strengthen zakat regulations.

\section{Reference:}

Al-Salih, A. N. (2020). The Role of Zakat in Establishing Social Welfare and Economic Sustainability: The Case of Saudi Arabia. International Journal of Financial Research, 11(6), 196. https://doi.org/10.5430/ijfr.v11n6p196

Ali, I., \& Hatta, Z. A. (2014). Zakat as a poverty reduction mechanism among the muslim community: Case study of Bangladesh, Malaysia, and Indonesia. Asian Social Work and Policy Review, 8(1), 59-70. https://doi.org/10.1111/aswp.12025

Alkire, S. (2010). Human Development: Definitions, Critiques, and Related Concepts Background paper for the 2010 Human Development Report.

Bahri, E. S. (2013). Zakat dan Pembangunan Sosial. July, x + 119 halaman.

Bremer, J. (2013). Zakat and Economic Justice: Emerging International Models and their Relevance for Egypt. Third Annual Conference on Arab Philantrophy and Civic Engagement, 51-74.

dkk., Z. N. A. (2018). Perilaku Muzakki dalam Membayar Zakat Melalui Transaksi Non-Tunai di Lembaga Inisiatif Zakat Indonesia (IZI) Surabaya. Iqtishodia: Jurnal Ekonomi Syariah, 3(1 SE-), 39-57. http://ejournal.alqolam.ac.id/index.php/iqtishodia Larticle/view/163

Dzikrulloh, D., \& Permata, A. R. E. (2019). Optimalisasi Zakat Sebagai Instrumen Modal Sosial Guna Mengatasi Masalah Kemiskinan Di Indonesia. Dinar : Jurnal Ekonomi dan Keuangan Islam, 5(1), 46-58. https://doi.org/10.21107/dinar.v5i1.5127

Fajarudin, I. (2019). Kontribusi Zakat Sebagai Pendapatan Negara Dan Instrumen Penerimaan Pajak (Studi Interpretif ). Pradigma Accountancy, 2(1), 25-38.

Hafidhuddin, D. (2008). The Power of Zakat Studi Perbandingan Pengelolaan Zakat Asia Tenggara, UIN-Malang Press, 2008,.
Hassan, K. (2010). An Integrated Poverty Alleviation Model Combining Zakat, Awqaf ad Micro-Finance. Seventh International Conference - The Tawhidi Epistemology: Zakat and Waqf Economy, Bangi 2010, January 2010.

Holil, H. (2019). Lembaga Zakat Dan Peranannya Dalam Ekuitas Ekonomi Sosial Dan Distribusi. Al-Infaq: Jurnal Ekonomi Islam (p-ISSN:2087-2178,eISSN:257-6453), 10(1), 13-27.

Ibrahim, P., Ali, M., Muridan, M., \& Mohd Jazid, A. I. (2020). Revisiting Zakat Distribution on Income Inequality and Welfare: The Malaysia Experience. al-Uqud: Journal of Islamic Economics, 4(1), 146. https://doi.org/10.26740/al-uqud.v4n1.p146-161

Ismail. (2005). Zakat Produktif: Sistem Alternatif dalam Pengentasan Kemiskinan. Pascasarjana UIN Syarif Hidaatullah.

Karuni, M. S. (2020). Pengaruh Dana Zakat Terhadap Pembangunan Manusia Di Indonesia. IQTISHADUNA: Jurnal Ilmiah Ekonomi Kita, 9(2), 174-185.

https://doi.org/10.46367/iqtishaduna.v9i2.245

Khasandy, E. A., \& Badrudin, R. (2019). The Influence of Zakat on Economic Growth and Welfare Society in Indonesia. Integrated Journal of Business and Economics, $3(1), \quad 65$. https://doi.org/10.33019/ijbe.v3i1.89

Murtala, M., Abioye, O., Har, M., \& Mohamad, S. (2011). Antecedents of Zakat Payers' Trust: The Case of Nigeria. International Journal of Economics, Management and Accounting, 19(3), 133-164.

Rahman, A. (2002). Doktrin Ekonomi Islam. Edisi Kedua. Penerbit Dana Bhakti Wakaf.

Ramadhita, R. (2012). Optimalisasi Peran Lembaga Amil Zakat Dalam Kehidupan Sosial. Jurisdictie, Jurnal Hukum dan Syariah, 3(1), 24-34. https://doi.org/10.18860/i.v0i0.2182

Ridho, A. (2014). Zakat dalam Perspektif Ekonomi Islam. Jurnal A-'Adl, 7(1).

Subekan, A. (2012). Zakat, Pendapatan Negara Yang Terabaikan.

Sudirman. (2007). Zakat dalam Pusaran Arus Modernitas. Malang: UIN-Malang Press.

Yusoff, W. (2008). Modern Approach of Zakat As an Economic and Social Instrument for Poverty Alleviation and Stability of Ummah. Jurnal Ekonomi \& Studi Pembangunan., 9(1), 105-118. https://doi.org/10.18196/jesp.9.1.1529 